\title{
The Market Value of CSR Performance Across Sectors
}

\author{
Karolina Daszynska-Zygadlo, Tomasz Slonski, Bartosz Zawadzki \\ Wroclaw University of Economics \\ 118/120 Komandorska st., 53-345 Wroclaw, Poland \\ E-mail.karolina.zygadlo@ue.wroc.pl,tomasz.slonski@ue.wroc.pl,b.zawadzki.ue@gmail.com
}

cross ref $\underline{\text { http://dx.doi.org/10.5755/j01.ee.27.2.13480 }}$

In this paper we investigate the relationship between Corporate Social Responsibility performance (CSP) and firms' financial standing - corporate financial performance (CFP) in ten Global Industry Classification System (GICS) sectors. The analysis of each sector provides unique opportunity of finding these CSR actions which nowadays play the most important role. We use Thomson Reuters ASSET4 ratings in order to proxy the CSR behaviour of 2428 companies from all over the world in the period of 2009-2012. We find CSR actions' effects measured by value increase as well as transitory effect on earnings conditional upon the company's sector. Firstly, we prove that eco-efficiency investments are value destructors in 8 out 10 sectors. For corporate governance we find significant results only in three sectors with ambiguous characteristic. Despite of adding the third, social dimension we observe relatively lesser impact of CSR actions on firms' financial performance in case of four sectors.

Keywords: Corporate Social Responsibility Performance, Financial Performance, Sector Analysis, Tobin's q, P/E ratio.

\section{Introduction}

Substantial attention in the literature had been drawn to the relation between corporate social responsibility (CSR), also specified as corporate social performance (CSP) and corporate financial performance (CFP) over the past thirty years.

It is also a growing concern topic at the capital markets, reflected in increasing value of assets under management in Socially Responsible Investment Funds, as well as many new financial products and services are being launched (Dziawgo, 2009). The study of Rogowski (2013) confirms also the increase interest of Polish companies in CSR performance and publishing social reports.

More than 100 studies have examined whether corporate social responsibility (CSR) metrics predict financial performance, with a variety of results (for reviews, see Margolis \& Walsh, 2003 and Margolis, Elfenbein \& Walsh, 2007).

But it doesn't seem that in these studies there has been reached a clear conclusion on the relationship between CSR and financial performance. In the process several arguments have been developed to explain the contradictory results underlying the lack of consensus. McWilliams and Siegel (2000), Rowley and Berman (2000) as well as Elsayed and Paton (2005) point to numerous biases and problems in previous work that encompass: model misspecification, omitted variables in the determinants of profitability, limited data (small samples, old periods), cross-sectional analysis invalid in the presence of significant firm heterogeneity, problems of measurement of CSR, and the wide diversity of measures used to assess financial performance. The problem that is also mentioned is the direction and mechanisms of causation. Whether CSR leads to superior financial performance, or whether financial performance is rather necessary condition for CSR, is the issue covered by only few papers (Waddock \& Graves, 1997; Margolis et al., 2007, Scholtens, 2008; Lioui \& Sharma, 2012).

The aim of the paper is to reveal how particular pillars of CSR performance impact market value of companies belonging to different sectors.

Our study attempts to show the contextuality of CSR performance and its influence on financial performance by conducting research on unique dataset with a separate result of CSR performance in three dimensions: Corporate Governance, Environmental and Social. At the same time we use contingency approach in order to fill in the gap in the literature of analyzing and finding differences between business sectors in the impact of CSR performance on financial performance.

The methods of the research are comparative analysis of literature, critical analysis, econometric analysis, and generalization.

We structure our paper in six sections: The second section discusses contextuality of Corporate Social Responsibility (CSR). In the third section, we analyze sector impact on CSR performance and deliver the hypothesis of the paper. Section four commences our empirical analysis by describing our data sets and methods. The fifth section discusses our empirical results. Section six presents the discussion and concludes.

\section{Contextuality of Corporate Social Responsibility Definition}

One of the major issues is a challenging process of reaching the agreement among the academics on a single, precise and general definition of corporate social responsibility (CSR). It could be even evaluated as unsuccessful given that a wide range of views have been expressed on questions concerning the scope and priority aligned to CSR (Hoepner et al., 2010). 
According to European Commission (2001) being socially responsible means that, beyond legal constraints, firms commit on a voluntary basis to bear the cost of more ethical behavior in $\mathrm{s}$ variety of practices, for example improving employment conditions and/or banning child labor in countries that do not respect human rights, protecting the environment and investing in abatement equipment to reduce the carbon footprint, developing partnerships with NGOs, or providing funds to charity, etc. (European Commission, 2001). Therefore, CSR is inherently multi-faceted and implies a multi-dimensional decision. Researchers often group those different dimensions into three main pillars: environmental, social and corporate governance (so-called ESG factors). These categories are also used in CSR ratings, scoring and models for firms' evaluation for inclusion in sustainability indexes, such as FTSE4GOOD, DJSI or STOXX Sustainability (Daszynska-Zygadlo, Ryszawska, 2014).

It could be stated that CSR involves taking actions which reduce the extent of externalized costs or avoid distributional conflicts. That approach is reflected in OECD materials, stating that the common aim of the governments adhering to the OECD guidelines to multinational enterprises on corporate responsibility is to encourage the positive contributions that multinational enterprises can make to economics, environmental and social progress and to minimize the difficulties to which their various operations may give rise. This could be understood as an interpretation of CSR activities as the ones that would increase the social value added by corporate activity, admitting the contextual approach towards it.

Contextuality of the concept is an often discussed matter and a field of disagreement, drawing attention to two utmost opinions being that a search for one common definition of CSR should be abandoned (van Marrewijk, 2003) and on the other extreme given that context specific definition of CSR would be less useful (Dahlsrud, 2008).

Explicit confirmation of importance of differentiating the types of CSR activities among different actors could be found in Global Reporting Initiative, recognized standard for CSR reporting worldwide. One can find there not only core guidelines for CSR reporting under any business conditions, but also complementing, additional guidance for particular sectors and nations. In many studies the moderate, intermediate approach is reflected in the explicit or implicit recognition of the CSR contextual nature (Matten \& Moon, 2008; Siegel \& Vitaliano, 2007). In the resent study of Wang and Berens (2015) contextuality of CSR has been recognized in previously defined by Carroll (1979, 1991) four types of CSR performance (i.e. economic, legal, ethical and philanthropic). They found out that each type of performance affect financial performance differently, additionally they distinct the impact on corporate reputation among public and financial stakeholders groups.

Hoepner et al. (2010) define a corporation as displaying social responsibility, when it engages itself in processes that appear to advance a general contextual social or environmental agenda beyond legal arrangements. Examples of general agendas across sectors could be easily found, among which there could be corporate codes of ethics and employee relations practices, but there exist very distinctive context specific opportunities to signal social responsibility. Just giving an example of car producers only which can introduce to the market hybrid vehicles or financial institutions only which can offer microfinance instruments.

"Managers should treat decisions regarding CSR precisely as they treat all investment decisions" (McWilliams, Siegel, 2001). The difficulty, however, is that the payoffs have been unclear because researchers have struggled for several decades to demonstrate a universal rate of return in a situation that clearly calls for a contingent perspective (Rowley, Berman, 2000; Ullmann, 1985). A contingent perspective argues that although all CSR activities are not profit maximizing, some may be, and so the careful use of CSR can fulfill management's fiduciary responsibilities (Barnett, 2007).

Taking into account the perspective of creating competitive advantage through realization of CSR strategy Juscius and Snieska (2008) state that company should find what kind of CSR activity is prior for it or is useful for competitive ability increase, especially that different stakeholders appreciate companies' social work through their totally differentiated interests. That is why companies must adjust to their contextual environment and value of CSR performance should be assessed according to its different pillars.

Therefore it is necessary to take into account the way the CSR performance is being measured and differentiate its impact on financial performance across industries (sectors).

\section{Research Hypothesis and Analysis of Sector Impact on CSR Performance}

Contingency perspective in previous studies was based on three conditional dimensions: CSR form, firm characteristics and time (Barnett, 2007) and national and industrial characteristics (Matten \& Moon, 2008; Rowley \& Berman 2000; Hoepner et al., 2010) as two additional ones. Taking into account that CSR form refers to specific CSR activities and it represents a contextual concept, the relevance of individual activities depends on its application context. Therefore what will be highly important for fossil fuel sector stakeholders will not be a top priority issue of financial sector stakeholders. This is why, as stated by Kempf and Osthoff (2007) the adoption of different CSR activities across firms in majority of cases is not significantly correlated. These activities will also differ in terms of impacting CFP.

Even thought substantial number of researchers have noticed the need for and called for research on the potential heterogeneity of CSR's impact on CFP across industries (Ullmann 1985; Hart 1995; Barnett, 2007; Godfrey \& Hatch, 2007), up to the date there have been only a few studies conducted in that field. Mainly focusing on one separate industry type (e.g. Simpson and Kohers, 2002) and some studies investigating the moderating effects of a specific parameters of industries (e.g. Hull and Rothenberg, 2008) with only one paper analyzing the effect of CSP on CFP across industries (Hoepner et al., 2010). Hoepner et al. (2010) taking the perspective of corporation and of the investor conducted a research aiming at finding differences in the CSP - CFP 
relationship among industries by adopting an unconditional measure of CSR that weighted its sub-indicators identically in any industrial context. The authors claim to achieve it by using a unique data sample from Innovest database.

In vast majority of the studies on CSP - CFP relationship described in paper analyzing 95 studies (Margolis and Walsh, 2001) number 1 control variable is industry, but this is a controlling variable for CFP and it does not control for industry drivers of CSP's effect on CFP. These studies implicitly assume that the CSP - CFP relationship is homogeneous across industries. Therefore, if evidence would be found suggesting a heterogeneous effect of CSP on CFP across industries, the results of many previous empirical studies of multiple industry datasets should be interpreted with slight more caution than up till now. Industry type is also included in the study of CSP CFP relationships among controlling variables treated as industry fixed effects, being coded into only three industries: manufacturing, service and financial in the work of Elsayed and Paton (2005) and Wang and Berens (2015).

Following Hoepner et al. (2010) conceptual framework we hypothesize that there exists contingency perspective on the effect of corporate social responsibility performance (CSP) on corporate financial performance (CFP) and it is contextual in respect to three different dimensions of CSR being - Environmental, Social and Governance. The concept of the study finds confirmation in statement of Rangan et al. (2015) that conclude about no logics or practical arguments behind that all companies should engage in the same types of CSR actions, since CSR programs are driven by diverse factors including industry, societal environments where businesses are being placed and motivations of people who staff, run and govern each company. We decided to separately verify the set of hypotheses about the impact of each dimension of CSR on Corporate Finance Performance in each sector defined as in Global Industry Classification System (GICS). Although there were many studies conducted in order to check the relationship of CSR and CFP and obtained results are mixed we believe that we can assume that if CSR has a positive effect on CFP that each dimension of CSR activities might also have a positive impact. But following the doubts from studies with mixed results we wish to verify how separating smaller more homogenic samples of companies from the same sectors will change the results. As well as dividing general, aggregated variable signifying the whole set of different type of CSR activities into categories we wish to test their isolated influence on CFP.

Our hypotheses are as follows:

H1: Corporate governance activities have positive impact on Corporate Financial Performance in each of GICS sectors

$\mathrm{H} 2$ : Environmental activities have positive impact on Corporate Financial Performance in each of GICS sectors.

H3: Social performance have positive effect on Corporate Financial Performance in each of GICS sectors.

Conducting our study on the basis of three dimensions of ASSET4 rating: Corporate Governance, Social and Environmental could give valuable insights and confirm the legitimacy of contingency perspective adoption and previous findings. We also add the regional perspective, controlling for regional location of the business, namely Asia, Europe and North America. In order to confirm heterogeneity across industries we have divided our sample into ten industries subsamples and checked the impact of each category of CSP (Corporate Governance, Environmental and Social) on the financial performance.

We do not control for industry drivers of CFP but we show how in particular sectors financial performance is impacted by CSR.

\section{Data Description and Methodology}

For a unique dataset, our empirical investigation allows us to analyze the relationship between CSP and CFP across ten industries across all the continents from two perspectives: the corporate (company financial efficiency) and the investor perspective who gets the information that is publicly accessible.

The CSR data about firms is taken from Thomson Reuters ASSET4 Database. To the three main proxy dimensions of corporate social responsibility (so-called pillars): environment, social and corporate governance, ASSET4 universe adds additional economic score as additional pillar of the performance assessment. We use the economic score as additional controlling variable for financial performance. Financial data has been obtained from the Thomson Reuters Datastream and Bloomberg databases. Research covers the period of 2009-2012 and 7942 observations.

ASSET4 gathers extensive, objective, quantitative and qualitative ESG data on almost 4000 global companies and scores them on four pillars. Research analysts collect more than 600 data points per company since fiscal year 2002 . Typical sources include stock exchange filings, CSR reports, annual reports, non-governmental organization websites, and news sources. Scores and data are provided transparently at all levels in the ASSET4 framework. All data must be objective and publicly available, though analysts are permitted to contact company investor relations offices to learn the location of public data. Obtaining data from several resources makes the information about companies performance more objective. Important thing is that it is not based only on what companies declare they do in their reports (or what would be even worse from the perspective of objectivity of the data - in the surveys) but it is supplemented by information provided by non-governmental organizations websites that usually are very alerted to misconducts of corporations and news sources that immediately report on violations and harmful performance of business entities.

Using this dataset makes our study unique in couple of ways: big size of the sample, even when it comes to industry subsamples; comprehensive measurement of each dimension of CSR on the basis of multiple ratios; transparency of data points used by ASSET4 in order to obtain the score. According to the best knowledge of authors no other research has been done on the basis of that data set up to that date. Table 1 presents the sample size with respect to sector defined as in Global Industry Classification System (GICS). 
Table 1

Observations by sector

\begin{tabular}{lc}
\hline Sector & Number of obs. \\
\hline Basic Materials & 1285 \\
Consumer Staples & 609 \\
Consumer Discretionary & 612 \\
Energy & 450 \\
Financial & 1119 \\
Healthcare & 396 \\
Industry & 1155 \\
Technology & 397 \\
Telecom & 633 \\
Utilities & 1286 \\
\hline
\end{tabular}

In order to reduce the effect called accounting illusion (Hoepner, 2010) we incorporate in our research simplified Tobin $q$ (the book value of assets approximate replacement costs as in Guenster et al., 2010) and PE ratio as a proxy of transitory effect of the current earnings change. We find Tobin's q as valuable measure of financial performance (Tobin 1969) since it captures market values of firm's goodwill. Therefore, any increase of $\mathrm{q}$ shows bigger sustainable competitive advantage within its sector. This advantage might reside in the company's brand name and reputation for quality, or from monopolistic or technological advantage, or perhaps on CSR activities. In such a situation, the firm is likely to trade on abnormally high $P E$ ratio, reflecting its ability to earn in excess of its cost of capital. This is the rationale for using PE ratio as another measure of financial performance.

There are two main determinants of $\mathrm{PE}$ ratio, the cost of capital and the rate of return spread. The cost of capital "brings" future earnings into the present value. Taking cost of capital alone, a low PE ratio implies high cost of capital. In turn, PE ratio increases if there is a positive rate of return (ROE) spread above the cost of capital. For this reason ROE becomes our control variable.

In our analysis it is important to know how CSR disbursements are recognized in accounting system. If capitalized it will be recognized in Tobin's q as a change in book value of assets. If expensed it will affect firm's earnings and therefore impacts PE ratio. It gives the additional reason of using Tobin's $\mathrm{q}$ and PE ratio in our research. Our financial performance is reflected in market value of company and is operationalized by two measures that complement each other.

Financial data for our research is divided into valuation proxy (dependent variable) and control (independent) variables taken from Thomson Reuters Datastream and Bloomberg databases. For Tobin's $q$ and PE ratio we have used the values provided by Thomson Reuters Datastream database. Following Barth et al. (1998), we assume that firm's value is influenced by firm's profitability, firm's size and sales growth. To enhance model's robustness we used a complete set of those variables. Return on Equity (RoE) is used as a measurement of firm's profitability; firm's size is defined as a logarithm of the market capitalization; sales growth as one-year revenue growth. Sales growth is used as a proxy for expansion rate, and market capitalization as a proxy for a firm's ability to seize growth opportunities and its overall risk exposure. Since the host country legal regulations might interfere with our results we introduce the region as a control variable.

Based on OLS (ordinary least squares) regression, we estimate two models (model 1) with simplified Tobin's $q$ and $\mathrm{PE}$ ratio as the dependent variables.

Following Guenster et al. (2010), we use trimmed (the procedure ensures a limited effect of outliers) dependent variables in logs. The trimming procedure eliminates potential outliers in the extreme left and right 0.5 percent of the distribution.

$$
\begin{aligned}
& \text { Model 1: } \\
& \quad \text { Value }_{i} \\
& \quad=\alpha_{0}+\alpha_{1} \text { Governance Score }_{i} \\
& +\alpha_{2} \text { Environmental Score }_{i}+\alpha_{3} \text { Social Score }_{i} \\
& +\sum_{j=1}^{3} \beta_{j} \text { Region }_{i, j}+\alpha_{4} \text { Economic }_{i}+\alpha_{5} \text { Market Cap }_{i} \\
& +\alpha_{6} \text { RoE }_{i}+\alpha_{7} \text { Sales growth }_{i}+\varepsilon i, \varepsilon i
\end{aligned}
$$

Where: Value $_{i}$, valuation proxy for sector $i$, Governance $_{i}$, Environmental $i$, Social Score $_{i}$ as well as Economic $_{i}$ - are the scores (ranging from 0 to 100) for particular pillars of the Reuters Assets 4 CSR ranking; $R o E_{i}$, Return on Equity; Market Cap ${ }_{i}$, logarithm of market capitalization; Sales growth, one-year revenue growth; Region $_{i, j}, 3$ dummy variables, distinguishing the country of registration of the company between North America, Europe and Asia; $\varepsilon_{i}$, residual.

\section{Results}

In table 2 we present the estimation results for years 2009-2012 where for each sector we run regression on trimmed Tobin's q.

Regarding the Corporate Governance pillar in the CSR universe we find the positive significant impact in the case of Materials, Financial and Industrial companies. Financial companies benefit the most from the Corporate Governance activities. On the other hand the Consumers Staples and Consumer Discretionary companies lose when expanding Corporate Governance efforts.

As for the Environmental dimension we find significant results which prove that Environmental efforts deteriorate companies performance measured by Tobin's $q$. The biggest negative influence is in the case of Materials and Utilities. Companies from Energy, Financial and Industrial sectors are relatively less punished for Environmental actions.

We find interesting results for Social actions' influence on Tobin's $q$. Only in the case of four sectors, namely Consumers Staples, Financial, Industrial and Utilities, we find significant results. Only for Industrial sector the impact is negative. This pillar of CSR actions has relatively lesser impact on dependent variable.

We decided to control results using a range of variables. For two financial variables and Market Cap we find positive strong impact. The ROE's positive influence is significant for all sectors. The biggest impact of ROE is for Consumers Discretionary and Consumers Staples. We observe less significant influence of sales growth on companies' financial standing. For six out of ten sectors 
the sales growth factor is significant and it reaches its maximum impact for Healthcare.

For many sectors the Market Cap maintains relatively highly important. The extent of Market Cap's impact is biggest for Materials and Consumer Staples, and only for Healthcare this factors is irrelevant.

We find versatile impact of companies geographical location on many sectors. European origins are important only for Healthcare companies. There is a large premium for being North American company in CSR universe for as much as seven sectors. For these sectors the location becomes the most important factor among control variables. On the other hand, for 5 sectors Asian location gives opposite results to North American ones. For example, in Material sector slope coefficient for North America is 0,130 while for Asia is $-0,161$.

Regression parameters estimates for Tobin's q

Table 2

\begin{tabular}{|c|c|c|c|c|c|}
\hline & Materials & Consumers Staples & Consumer Discretionary & Energy & Financials \\
\hline Governance & $0.0010^{* *}$ & -0.0015 & $-0.0018^{* *}$ & 0.0006 & $0.0021 * * *$ \\
\hline Environmental & $-0.0052 * * *$ & -0.0011 & $-0.0036^{* * *}$ & $-0.0020 * *$ & $-0.0023^{* * * *}$ \\
\hline Social & 0.0007 & 0.0007 & $0.0019 * *$ & -0.0006 & $0.0011 * *$ \\
\hline Asia & $-0.1615^{* * *}$ & -0.0655 & $-0.3529 * * *$ & -0.0266 & 0.0547 \\
\hline Europe & 0.0163 & -0.0416 & 0.0619 & 0.0096 & 0.0182 \\
\hline N. America & $0.1296 * * *$ & 0.0538 & $0.1147 * *$ & 0.0233 & 0.0146 \\
\hline Economic & 0.0001 & -0.0003 & 0.0002 & $0.0015 * *$ & $-0.0008 * *$ \\
\hline Market Cap & $0.0488 * * *$ & $0.0332 * * *$ & $0.0457 * * *$ & $0.0182 * * *$ & $-0.0063^{*}$ \\
\hline Sales growth & 0.0006 & $0.0026^{* * *}$ & $0.0040^{* * *} *$ & $0.0010 *$ & -0.0003 \\
\hline R-squared & $22.02 \%$ & $55.29 \%$ & $46.97 \%$ & $23.54 \%$ & $29.49 \%$ \\
\hline \multicolumn{6}{|l|}{ Adjusted } \\
\hline \multirow[t]{2}{*}{ R-squared } & $21.47 \%$ & $54.61 \%$ & $46.17 \%$ & $21.95 \%$ & $28.91 \%$ \\
\hline & Healthcare & Industrials & Information Technology & Telecom Services & Utilities \\
\hline Governance & 0.0014 & $0.0009 * *$ & 0.0019 & -0.0002 & -0.0006 \\
\hline Environmental & $-0.0030 * *$ & $-0.0020 * * *$ & $-0.0039 * * *$ & 0.0004 & $-0.0047 * * *$ \\
\hline Social & 0.0018 & $-0.0009 *$ & -0.0008 & -0.0010 & $0.0032 * * *$ \\
\hline Europe & $0.1346^{*}$ & 0.0265 & -0.0260 & 0.0498 & 0.0397 \\
\hline N. America & $0.1646^{* *}$ & $0.1300^{* * *}$ & -0.0636 & $0.1930 * * *$ & $0.1604 * * *$ \\
\hline Economic & 0.0012 & $0.0009^{*}$ & 0.0001 & $0.0012 *$ & 0.0006 \\
\hline Market Cap & 0.0118 & $0.0278^{* * *} *$ & $0.0840 * * *$ & $0.0190^{* * *}$ & $0.0262 * * *$ \\
\hline ROE & $0.0116^{* * *}$ & $0.0093 * * *$ & $0.0070^{* * * *}$ & $0.0089 * * *$ & $0.0107 * * *$ \\
\hline Sales growth & $0.0066^{* * *}$ & 0.0007 & $0.0069 * * *$ & 0.0011 & 0.0005 \\
\hline R-squared & $27.76 \%$ & $31.52 \%$ & $34.66 \%$ & $23.78 \%$ & $31.91 \%$ \\
\hline \multicolumn{6}{|l|}{ Adjusted } \\
\hline R-squared & $26.07 \%$ & $30.98 \%$ & $33.12 \%$ & $22.67 \%$ & $31.43 \%$ \\
\hline
\end{tabular}

Note: $* * *, * *, *$ represent significance on $1 \%, 5 \%$ and $10 \%$ levels respectively

Table 3

Regression parameters estimates for PE ratio

\begin{tabular}{|c|c|c|c|c|c|}
\hline & Materials & Consumers Staples & Consumer Discretionary & Energy & Financials \\
\hline Governance & $0.0032 * * *$ & 0.0005 & 0.0008 & 0.0003 & $0.0036^{* * *}$ \\
\hline Environmental & $-0.0060 * * *$ & $-0.0026^{* *}$ & $-0.0036^{* * *}$ & -0.0019 & $-0.0045^{* * *} *$ \\
\hline Social & 0.0005 & $0.0028 * *$ & 0.0011 & 0.0013 & $0.0026^{* *}$ \\
\hline Asia & $-0.3513 * * *$ & -0.0964 & $-0.6837 * * *$ & -0.1615 & -0.0008 \\
\hline Europe & $-0.1533 * * *$ & -0.0523 & -0.0724 & -0.0509 & $-0.2051 * * *$ \\
\hline N. America & -0.0439 & 0.0682 & -0.0195 & -0.0741 & $-0.1726^{* * *}$ \\
\hline Economic & -0.0001 & -0.0013 & 0.0007 & 0.0010 & -0.0003 \\
\hline Market Cap & $0.0691 * * *$ & $0.0358 * * *$ & $0.0695^{* * *} *$ & $0.0328 * * *$ & -0.0010 \\
\hline ROE & $0.0110 * * *$ & $0.0273 * * *$ & $0.0134 * * *$ & $0.0121 * * *$ & $0.0245^{* * *}$ \\
\hline Sales growth & $0.0019 * * *$ & $0.0027 * *$ & $0.0107 * * *$ & $0.0034 * * *$ & 0.0000 \\
\hline R-squared & $25.34 \%$ & $62.14 \%$ & $35.44 \%$ & $21.34 \%$ & $26.16 \%$ \\
\hline \multicolumn{6}{|l|}{ Adjusted } \\
\hline \multirow[t]{2}{*}{ R-squared } & $24.81 \%$ & $61.57 \%$ & $34.47 \%$ & $19.27 \%$ & $25.41 \%$ \\
\hline & Healthcare & Industrials & Information Technology & Telecom Services & Utilities \\
\hline Governance & 0.0020 & $0.0033^{* * *}$ & $0.0044 * * *$ & $0.0033 * * *$ & -0.0010 \\
\hline Environmental & $-0.0048 * *$ & -0.0009 & $-0.0060 * * *$ & -0.0002 & $-0.0067 * * *$ \\
\hline Social & 0.0045 & -0.0001 & 0.0014 & -0.0001 & $0.0067 * * *$ \\
\hline Asia & -0.1359 & $-0.2248 * * *$ & $-0.8530 * * *$ & $-0.1901 *$ & $-0.3407 * * *$ \\
\hline Europe & 0.1431 & $-0.0935^{*}$ & 0.0062 & 0.0000 & 0.0053 \\
\hline N. America & 0.0562 & 0.0968 & $-0.2431^{*}$ & -0.0232 & $0.2739 * * *$ \\
\hline Economic & 0.0010 & -0.0006 & -0.0016 & -0.0011 & -0.0009 \\
\hline Market Cap & $0.0333 * *$ & $0.0272 * * *$ & $0.1146^{* * * *}$ & $0.0400 * * *$ & $0.0418^{* * *}$ \\
\hline ROE & $0.0142 * * *$ & $0.0192 * * *$ & $0.0089 * * *$ & $0.0161 * * *$ & $0.0193 * * *$ \\
\hline Sales growth & $0.0049 * *$ & $0.0025^{* * *}$ & $0.0082 * * *$ & $0.0025^{* *}$ & 0.0010 \\
\hline R-squared & $27.22 \%$ & $39.59 \%$ & $38.47 \%$ & $31.08 \%$ & $35.15 \%$ \\
\hline \multicolumn{6}{|l|}{ Adjusted } \\
\hline R-squared & $25.52 \%$ & $39.12 \%$ & $37.02 \%$ & $30.07 \%$ & $34.68 \%$ \\
\hline
\end{tabular}

Note: $* * *, * *, *$ represent significance on $1 \%, 5 \%$ and $10 \%$ levels respectively 
Number of significant parameters in Tobin's $q$ and PE regressions

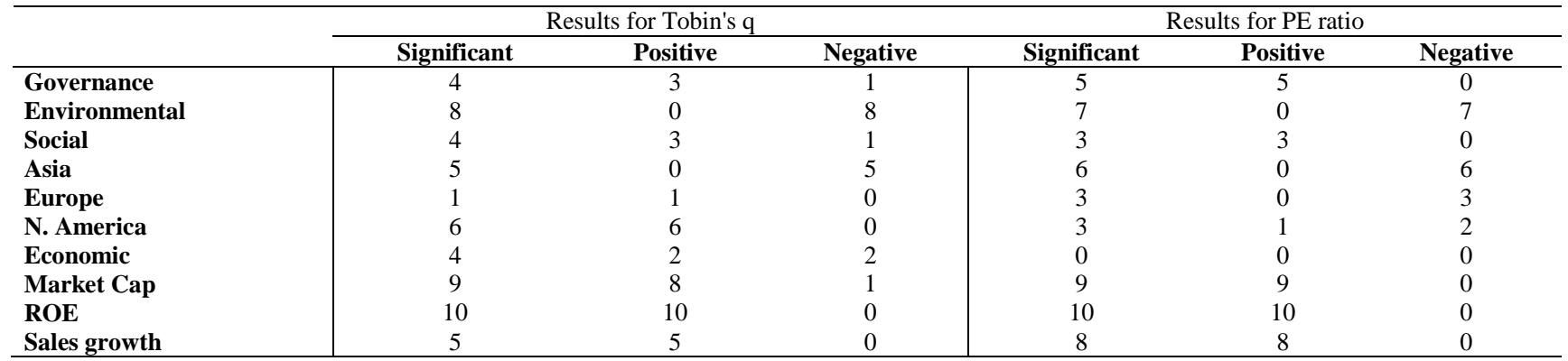

Table 3 presents the regression models parameters for $\mathrm{PE}$ ratio. Using the same data set we receive models with similar explanatory power. Table 4 presents the number of significant appearances for each variable together with the coefficients sign. The number of sectors sensitive to the CSR actions is similar, although not all of them are present in the left and right panel of table 4.

The general observations are as follows. Regarding the $\mathrm{PE}$ ratio increase the Governance efforts are welcomed in 5 sectors and for each sector the impact is positive. For these sectors the impact is relatively small and similar one to another since the range is between 0,0032 for Materials and 0,0044 for Information Technology. For Tobin's q the result are ambiguous but only one negative impact proved to be statistically valid.

Similar to our findings for Tobin's q regressions the Environmental actions tax firm's financial performance. The PE decreasing impact is for 7 out of 10 sectors ( 8 sectors in Tobin's q regressions).

For PE regressions Social dimension proved to be valid in 3 sectors. Once again the regressions on Tobin's q gives the vague results since 1 sector out of 4 , namely Industrials, shows negative impact.

The analysis of control variables indicates that there is still a discount for being Asian company. However, the premium for North American companies vanished when regressing against PE ratios, with exception for Utilities. It seems that values of North American assets are higher comparing to its historical costs (high Tobin's q) but it is not supported by their abnormal returns. The impact of ROE on market value is very important and statistically significant in every sector. The results are similar for Market Capitalization with lesser impact on Financials and no statistically significant influence on Healthcare.

The list of CSR sensitive sectors is changing when choosing different measure of financial performance. For Social dimension the positive results in both Tobin's q and PE ratio are for Materials, Financials, Industrials. As for Consumer Discretionary a small, negative impact on Tobin's q does not correspond with significant change in $\mathrm{PE}$ ratio. The opposite results are observed for Information Technology and Telecom Services.

For Environmental efforts we observe strong negative impact on both value measures (both insignificant for Energy). For Consumer Staples the result becomes significant in case of PE change, and for Industrials the result is significant in case of Tobin's q change.
Among three CSR dimensions the Social one has the least impact on firm's value measures. It has positive impact on Tobin's $\mathrm{q}$ and value measures in case of Financials and Utilities. The increase in $\mathrm{PE}$ ratio is significant for Consumer Staples whereas the positive change in Tobin's q is significant only for Consumer Discretionary. There is a negative and less significant influence of Social action within Industrial sector measured by Tobin's q.

\section{Discussion and Conclusions}

Our research targets are: (1) to serve as a valuable comparison to up to date studies, (2) to present complimentary results obtained on the basis of different approaches. In order to confirm heterogeneity across industries we have divided our sample into ten industries subsamples and checked the impact of each category of CSP (Corporate Governance, Environmental and Social) on the financial performance.

Taking three CSR dimensions into account we find the Social performance relatively the least important. This CSR's dimension gives statistically significant change only for four sectors with respect to Tobin's q (in case of $\mathrm{PE}$ ratio positive influence for three sectors). According to Siegel and Vitaliano's (2007) results the connection of CSR and CFP depends on the type of consumers goods sold. We confirm that firms that sell credence services (e.g. financials) improve their performance while enhancing Social and Corporate Governance performance. The same commitment of a Utility sector towards consumers may explain the positive impact of Social performance. Following Porter and Kramer (2006) the Social performance in sectors depending on large low-cost workforces is costly and less rewarding. For this reason, we find the negative impact of the Social activities in Industry sector (only in Tobin's q regressions). On the basis of these findings we can state that the impact of Social performance on CFP differs among the sectors, which confirms the contingency effect.

It can also be stated that in case of Financials and Utilities sectors we confirmed the hypothesis about positive impact of Social dimension of CSR on financial performance exemplified by increasing both Tobin's q and $\mathrm{PE}$ ratio. It means that within these two sectors companies Social actions are able to increase the return earned in excess of the cost of capital and earnings will decrease in short-term below their abnormal level. For Consumer 
Discretionary the value increasing strategy is not accompanied by current earnings effect while in case of Consumer Staples sectors Social actions push current earnings transitorily below their normal level. In remaining sectors we haven't found any significant relation.

The Corporate (Governance) activities plays different role among sectors. It is value creating activity (higher Tobin's q) for: Materials, Financial and Industrials sectors despite lowering current abnormal earnings. Regarding PE ratio, when the Corporate actions become statistically significant ( 5 cases) they always reduce the potential to earn current abnormal earnings. The minor value destruction effect is observed only in Consumer Discretionary sector without significant change in current abnormal earnings.

Despite of the relative importance of Corporate Governance actions stated by Zingales (2000) the hypothesis of positive impact of Corporate Governance actions can be confirmed only in case of three sectors and rejected in the case of one.

Our main findings, however, are related to Environmental performance. We find this factor significant for Tobin's q in 8 sectors but in each case the impact is negative (PE ratio decrease in case of 7 sectors). Previous studies of Marsat and Williams (2011), followed by Slonski et al. (2014), analyzing general linkage, without differentiating for sectors confirm these findings. According to Derwall et al. (2005) and Semenova and Hassel (2008) the CSR's positive effects are difficult to achieve in environmentally sensitive sectors due to higher cost of environmental performance. The biggest reduction of assets' market-to-book value is in Materials and in Utilities sectors. Similarly to Padgett and Galan (2010) we find that manufacturer's environmental actions affect the CFP to a stronger degree.

When it comes to Environmental performance in 8 sectors (Materials, Consumer Discretionary, Financials, Healthcare, Industrials, Information Technology, and Utilities) we reject the hypothesis about positive impact of this dimension on value creating strategy.

It is worth mentioning that each sector benefits/looses from CSR actions to the different extent. Some of them are immune to the CSR actions (i.e. Telecom Services is sensitive only to Governance actions when measured with $\mathrm{PE}$ ratio change). Energy and Healthcare sectors are sensitive towards Environmental actions only. For the Consumer Staples only the Governance and Environmental actions are significant.

Therefore on the basis of these findings we can confirm that there exists contingency perspective on the effect of corporate social responsibility performance (CSP) on corporate financial performance (CFP) which can be observed by statistically significant differentiated results across ten analyzed sectors.

There are practical implications for managers and owners of the companies. One must be aware that the CSR rating is a relative measure of the firm's performance. For a firm to climb up to the rating's top means reaching for the target above sector's average which is continuously changing from year to year. Managers must accept the fact that reaching for excessive environmental goals systematically reduces market value of the firm. For the market regulators it does stress the importance of enhancing the environmental regulation at the country level. Our research confirms that managers need to choose carefully CSR goals because their success depends on industry. Only for some industries Corporate Governance actions create additional market capital measured by Tobin's q but Social actions are welcomed by investors for firm's from merely two industries.

We need to be aware of limitation of conclusions made on the basis of obtained results. One needs to keep in mind, that in the case of CSR investments the valuation is subject to imperfect and incomplete markets. The market for CSR actions is highly imperfect because the connection between the created value and cost can vary significantly. Alternatively stated, the expenditure on CSR is often a key value driver (or, indeed, value destructor).

On the other hand, CSR actions tend to be either unique in nature, or inseparable from the company. CSR creates moral capital which is rarely traded and typically without market prices. For these reasons, the market incompleteness must be considered as the main valuation problem.

Interesting direction of further study would be to refer to shared value creation in value creation chain as suggested in work on framework for integration of CSR into value creation chain of Juscius and Jonikas (2013) and conduct study on the given sample with that wider perspective.

Other studies show, among which a recent one by Ortas et al. (2015) that firms from different countries adopt different management practices, implement different organizational choices and weight business objectives differently (such as profitability, growth or CSR). Therefore, even the adoption of the same voluntary CSR initiative - the UNGC - corporate environmental, social and governance performance is influenced by institutional and stakeholders' pressures which are of different nature among the businesses geographic spread. It indicates that among different sectors specific performance there could be additional potential differences resulting from the aforementioned arguments confirmed by studies on Spanish, French and Japanese firms conducted by Ortas $e t$ al. (2015). Our results on differences among regions of the world could be extended by analysis of CSR performance across countries.

Testing three dimensions of CSR actions using an entire sector of companies could be perceived as overall vague notion and might hide significant differences between sector's leaders and procrastinators. We think that further evidence is required based on portfolios of companies to confirm the reliability of the measures. 


\section{Acknowledgment}

„Publication was prepared based on research financed from the scientific grant for years 2012-2014 from Polish National Center of Science no 2011/03/B/HS4/05359 entitled "Wpływ społecznie odpowiedzialnych działań przedsiębiorstwa (CSR) najego wartość".

\section{References}

Barnett, M. L. (2007). Stakeholder influence capacity and the variability of financial returns to corporate social responsibility. Academy of Management Review, 32 (3), 794-816. http://dx.doi.org/10.5465/AMR.2007.25275520

Barth, M. E., Beaver, W. H., \& Landsman, W. R. (1998). Relative valuation roles of equity book value and net income as a function of financial health. Journal of Accounting and Economics, 25, 1-34. http://dx.doi.org/10.1016/S01654101(98)00017-2

Carroll, A. B. (1979). A three-dimensional conceptual model of corporate social performance. Academy of Management Review, 4, 497-505.

Carroll, A. B. (1991). The pyramid of corporate social responsibility: Toward the moral management of organizational stakeholders. Business Horizon, 34 (4), 39-48. http://dx.doi.org/10.1016/0007-6813(91)90005-G

Dahlsrud, A. (2008). How Corporate Social Responsibility is Defined: an Analysis of 37 Definitions. Corporate Social Responsibility and Environmental Management, 15 (1), 1-13. http://dx.doi.org/10.1002/csr.132

Daszynska-Zygadlo, K. and Ryszawska, B. (2014). Synthetic measures of corporate sustainability of public companies. [in:] D. Zarzecki, Narzędzia zarządzania finansami, Scientific Papers no 804, Finance, Capital Market, Insurance, 67, 613-628.

Derwall, J., Guenster, N., Bauer, R., \& Koedijk, K. (2005). The eco-efficiency premium puzzle. Financial Analysts Journal 61(2), 51-63. http://dx.doi.org/10.2469/faj.v61.n2.2716

Dziawgo, L. (2009). Spoleczna odpowiedzialność biznesu jako czynnik konkurencyjny na wspólczesnym rynku kapitalowym (CSR - Corporate Social Responsibility as a Competitive Factor on the Modern Capital Market). Zeszyty Naukowe Uniwersytetu Szczecinskiego. Finanse. Rynki finansowe. Ubezpieczenia, 16, 269-278.

Elsayed, K., \& Paton, D. (2005). The Impact of Environmental Performance on Firm Performance: Static and Dynamic Panel Data Evidence. Structural Change and Economic Dynamics, 16, 395-412. http://dx.doi.org/10.1016/ j.strueco.2004.04.004

European Commission. (2001). Promoting a European framework for corporate social responsibility. Green Paper. Luxembourg: Office for Official Publications of the European Communities.

Godfrey, P. C., \& Hatch, N.W. (2007). Researching Corporate Social Responsibility: An agenda for the 21st Century. Journal of Business Ethics, 70, 87-98. http://dx.doi.org/10.1007/s10551-006-9080-y

Guenster, N., Bauer, R., Derwall, J., \& Koedijk, K. (2010). The economic value of corporate eco-efficiency, European Financial Management, 17 (4), 679-704. http://dx.doi.org/10.1111/j.1468-036X.2009.00532.x

Hart, S. L. (1995). A Natural-Resource-Based View of the Firm. Academy of Management Review, 20 (4), $986-1014$.

Hoepner, A. G. F. (2010). Corporate Social vs. Financial Performance Research: Could the positive link be an Illusion? Accounting Working Paper, School of Management, University of St. Andrews.

Hoepner, A. G. F., Yu, P. S., \& Ferguson, J. (2010). Corporate Social Responsibility Across Industries: When Can Who Do Well by Doing Good? (March 1, 2010). Available at SSRN: http://ssrn.com/abstract=1284703

Hull, C. E., \& Rothenberg, S. (2008). Firm Performance: the interactions of corporate social performance with innovation and industry differentiation. Strategic Management Journal, 29, 781-789. http://dx.doi.org/10.1002/smj.675

Kempf, A., \& Osthoff, P. (2007). The Effect of Socially Responsible Investing on Portfolio Performance. European Financial Management, 13 (5), 908-922. http://dx.doi.org/10.1111/j.1468-036X.2007.00402.x

Juscius, V., \& Jonikas, D. (2013). Integration of CSR into Value Creation Chain: Conceptual Framework. Inzinerine Ekonomika - Engineering Economics, 24(1), 63-70.

Juscius, V., \& Snieska, V. (2008). Influence of Corporate Social Responsibility on Competitive Abilities of Corporations. Inzinerine Ekonomika - Engineering Economics, 58(3), 34-44.

Lioui, A., \& Sharma, Z. (2012). Environment Corporate Social Responsibility and Financial Performance: Disentangling direct and indirect Effects. Ecological Economics, 78, 100-111. http://dx.doi.org/10.1016/j.ecolecon.2012.04.004

Margolis, J. D., \& Walsh, J. P. (2001) People and Profits? The Search for a Link between a Company's Social and Financial Performance. Mahwah: Lawrence Erlbaum Associates.

Margolis J., \& Walsh, J. (2003). Misery loves Companies: Rethinking Social Initiatives by Business. Administrative Science Quarterly, 48, 268-305. http://dx.doi.org/10.2307/3556659 
Margolis, J. D., Elfenbein, H. A., \& Walsh, J. P. (2007). Does it pay to be good? An analysis and redirection of research on the relationship between corporate social and financial performance. (Working Paper, Harvard University), Available: http://stakeholder.bu.edu/Docs/Walsh,\%20Jim\%20Does\%20It\%20Pay\%20to\%20Be\%20Good.pdf.

Marrewijk, M. van (2003). Concepts and Definitions of CSR and Corporate Sustainability: Between Agency and Communion. Journal of Business Ethics, 44 (2/3), 95-105. http://dx.doi.org/10.1023/A:1023331212247

Marsat, S., \& Williams, B. (2011). CSR and Market Valuation: International Evidence, International Conference of the French Finance Association (AFFI). May 11-13, 2011. Available at SSRN: http://ssrn.com/abstract=1833581

Matten, D., \& Moon, J. (2008). Implicit and explicit CSR: A conceptual framework for a comparative understanding of corporate social responsibility. Academy of Management Review, 33 (2), 404-424. http://dx.doi.org/10.5465/ AMR.2008.31193458

McWilliams, A., \& Siegel, D. (2001). Corporate Social Responsibility: Theory of the Firm Perspective. Academy of Management Review, 26 (1), 117-127.

Ortas, E., Alvarez, I., Jaussaud, J., \& Garayar, A. (2015). The impact of institutional and social context on corporate environmental, social and governance performance of companies committed to voluntary corporate social responsibility initiatives. Journal of Cleaner Production, 108 (2015), 673-684. http://dx.doi.org/10.1016 /j.jclepro.2015.06.089

Padgett, R. C., \& Galan, J.I. (2010). The effect of R\&D intensity on corporate social responsibility. Journal of Business Ethics, 93, 407-418. http://dx.doi.org/10.1007/s10551-009-0230-x http://dx.doi.org/10.1007/s10551-009-0230-x

Porter, M. E., \& Kramer, M. R. (2006). Strategy \& Society. The Link between Competitive Advantage and Corporate Social Responsibility. Harvard Business Review, 84 (12), 78-92.

Rangan, K., Chase, L., \& Karim, S. (2015). The big idea. The truth about CSR, Harvrd Business Review, JanuaryFebruary 2015, 40-49.

Rogowski, W. (2013). Examples of CSR related activities in Polish companies / Miejsce spolecznej odpowiedzialności w strategiach przedsiębiorstw, Organization and Management, 1 (154), 65-72. http://dx.doi.org/10.2478/oam-2013-0005

Rowley, T., \& Berman, S. (2000). A Brand New Brand of Corporate Social Performance. Business \& Society, 39 (4), $397-$ 418. http://dx.doi.org/10.1177/000765030003900404

Salo, J. (2008). Corporate Governance and Environmental Performance: Industry and Country Effects. Competition and Change, 12 (4), 328-354.http://dx.doi.org/10.1179/102452908X357293

Scholtens, B. (2008). A note on the Interaction between Corporate Social Responsibility and Financial Performance. Ecological economics, 68(1/2), 46-55. http://dx.doi.org/10.1016/j.ecolecon.2008.01.024

Semenova, N., \& Hassel, L. G. (2008). Industry Risk Moderates the Relation between Environmental and Financial Performance. (Sustainable Investment Research Platform Working Papers 08-02), Available: http://web.abo.fi/fak/esf/fei/redovisa/kurser/Lasse/Mistra\%20wp/sirp\%20wp 2008$02 \% 20$ Semenova\%20and\%20Hassel.pdf.

Siegel, D. S., \& Vitaliano, D. F. (2007). An Empirical Analysis of Strategic Use of Corporate Social Responsibility. Journal of Economics \& Management Strategy, 16 (3), 773-792. http://dx.doi.org/10.1111/j.1530-9134.2007.00157.x

Simpson, W. G., \& Kohers, T. (2002). The Link between Corporate Social and Financial Performance: Evidence from the Banking Industry. Journal of Business Ethics, 35 (2), 97-109. http://dx.doi.org/10.1023/A:1013082525900

Slonski, T., Daszynska-Zygadlo, K., \& Zawadzki, B. (2014). Relation of CSR and Market Measures of Financial Performance: International Evidence. European Financial Systems 2014, 542-549.

Waddock, S. A., \& Graves, S. B. (1997). The Corporate Social Performance-Financial Performance Link. Strategic Management Journal, 18(4), 303-319. http://dx.doi.org/10.1002/(SICI)1097-0266(199704)18:4<303::AIDSMJ869>3.0.CO;2-G

Wang, Y., \& Berens, G. (2015). The Impact of Four Types of Corporate Social Performance on Reputation and Finance Performance. Journal of Business Ethics, 131, 337-359. http://dx.doi.org/10.1007/s10551-014-2280-y

Ullmann, A. A. (1985). Data in Search of a Theory: A critical examination of the relationships among social performance, social disclosure, and economic performance of U.S. firms. Academy of Management Review, 10 (3), $540-557$. http://dx.doi.org/10.5465/amr.1985.4278989

Tobin, J. (1969). A General Equilibrium Approach to Monetary Theory. Journal of Money, Credit and Banking, 1, 15-29. http://dx.doi.org/10.2307/1991374

Zingales, L. (2000). In Search of New Foundations. Journal of Finance, 55, 1623-1625. http://dx.doi.org/10.1111/00221082.00262

The article has been reviewed.

Received in October 2015; accepted in April, 2016. 